\title{
Green turtle diet is dominated by seagrass in the Western Indian Ocean except amongst gravid females
}

\author{
Holly J. Stokes ${ }^{1}$. Jeanne A. Mortimer ${ }^{2,3} \cdot$ Graeme C. Hays $^{4} \cdot$ Richard K. F. Unsworth ${ }^{1}$. Jacques-Olivier Laloë ${ }^{4}$. \\ Nicole Esteban ${ }^{1}$ (D)
}

Received: 16 November 2018 / Accepted: 9 September 2019 / Published online: 30 September 2019

(c) The Author(s) 2019

\begin{abstract}
Green turtles (Chelonia mydas) are key herbivores of tropical and subtropical neritic habitats and play a major role in structuring seagrass meadows. We present the first detailed assessment of green turtle diet in the Western Indian Ocean using the gut contents of salvaged animals from three atolls in the Republic of Seychelles separated from each other by 400-825 km: Cosmoledo (adults, $n=12$ ), Farquhar (adults, $n=33$; immature, $n=1$ ) collected in 1982-1983; and Desroches (immatures, $n=8)$ in 2016-2018. We report the first comparison of the diets of gravid females $(n=17)$, males $(n=26)$ and non-breeding females $(n=2)$ at sites providing both foraging and breeding habitat. Seagrass (mostly Thalassodendron ciliatum) dominated the diet, accounting for $95 \%$ of the mean gut content biomass for males and non-breeding females but only $58 \%$ for gravid females, alongside relatively large amounts of substrate (14\%) and macroalgae (13\%). Satellite tracking of post-nesting green turtles from Chagos Archipelago in 2016 located foraging sites at Farquhar Atoll that coincided with capture locations of 26 of the 33 adult turtles sampled there in 1983. In situ surveys of those sites in 2018 revealed extensive nearly monospecific beds of T. ciliatum. The prominence of seagrass in the diet of green turtles and connectivity between foraging and nesting habitats throughout the region illustrate the need to conserve and monitor seagrass habitats of the Western Indian Ocean especially in the context of changing green turtle population densities.
\end{abstract}

\section{Introduction}

Green turtles (Chelonia mydas) are marine ecosystem engineers that structure seagrass meadows through their foraging activities, often increasing its complexity (Coleman and Williams 2002) or, conversely, reducing species composition (Kelkar et al. 2013a; Lal et al. 2010) and production rates

Responsible Editor: P. Casale.

Reviewed by J A. Seminoff and an undisclosed expert.

Nicole Esteban

n.esteban@swansea.ac.uk

1 Seagrass Ecosystem Research Group, Department of Biosciences, Swansea University, Swansea SA2 8PP, Wales, UK

2 Island Conservation Society, Point Larue, Mahé, Republic of Seychelles

3 Department of Biology, University of Florida, Gainesville, FL 32611, USA

4 School of Life and Environmental Sciences, Deakin University, Geelong, VIC 3280, Australia
(Kelkar et al. 2013b). There is increasing evidence that this functioning helps to provide seagrass habitats with greater resilience to anthropogenic impacts (Christianen et al. 2012). Changes in green turtle density at foraging sites will, thus, have a consequence for seagrass ecosystem health. Due to numerous anthropogenic threats and population declines, the green turtle had been listed as globally endangered on the IUCN Red List (Seminoff 2004), but long-term population recovery, thanks to successful conservation strategies such as protection of turtles and their habitats at nesting sites, has led to long-term population recovery. This is reflected in recent and ongoing IUCN downlisting of various green turtle subpopulations around the world (e.g., to "least concern" for the Hawaiian and South Atlantic subpopulations (Chaloupka and Pilcher 2019; Broderick and Patricio 2019) and to Vulnerable for the North Indian Ocean subpopulation (Mancini et al. 2019) and, in literature, documenting of increasing population trends globally (Chaloupka et al. 2008; Seminoff et al. 2015; Mazaris et al. 2017), including upward trends in the Western Indian Ocean (Bourjea et al. 2007; Lauret-Stepler et al. 2007; Mortimer et al. 2011). 
Upon leaving the nesting beach as hatchlings, young green turtles occupy open ocean pelagic habitats (Bjorndal 1997). Post-hatchling green turtles are believed to spend their first 3-5 years in open ocean pelagic habitat where they attain carapace lengths of $25-35 \mathrm{~cm}$ feeding primarily on jellies and salps and then recruit to neritic habitats (Reich et al. 2007). Ontogenetic dietary change is complex and varies regionally (e.g., Cardona et al. 2010; Fukuoka et al. 2019). Typically, the diet is omnivorous during the early pelagic stages and becomes primarily herbivorous after recruitment to the neritic zone (e.g., Howell et al. 2016; Vélez-Rubio et al. 2016; Burgett et al. 2018). In the Central North Pacific, however, some individuals up to $70 \mathrm{~cm}$ curved carapace length (CCL) forage pelagically on a primarily carnivorous diet (Parker et al. 2011). At some neritic foraging habitats, seagrass predominates in the diet (e.g., Mortimer 1981; Vander Zanden et al. 2013); while at other sites, macroalgae is the primary food source (e.g., Garnett et al. 1985; Prior et al. 2016). Even terrestrial plant material, especially mangrove leaves and propagules (or seeds), can feature prominently in green turtle diets (Arthur et al. 2009; Limpus and Limpus 2000; Nagaoka et al. 2012). Contrary to the long-held belief that green turtles are strictly herbivorous, however, animal matter ranging from accidentally ingested small hydrozoans and bryozoans that encrust plant material to purposefully consumed sponges (Mortimer 1981) and significant amounts of gelatinous macrozooplankton (e.g., Amorocho and Reina 2007; Burkholder et al. 2011; Fukuoka et al. 2019; González Carman et al. 2014; Quiñones et al. 2010) have been reported in the diet of both juvenile and adult green turtles.

Food selection may correlate with differences in intestinal microflora (Bjorndal 1980), which varies as turtles transition from pelagic to neritic habitats (Campos et al. 2018; Price 2016) and with state of health (Ahasan et al. 2017). It follows that intestinal microflora typical of individuals that feed on seagrass likely differs from that of algivores and they are less efficient at digesting algae and vice versa (Bjorndal et al. 1991), but diets comprising large amounts of both seagrass and algae are also sometimes reported (e.g., López-Mendilaharsu et al. 2005; Shimada et al. 2014; Whiting et al. 2014). Stable isotope studies have been used to show that individuals in the same area can have long-term dietary preferences (Thomson et al. 2018). On the other hand, abrupt shifts between algae, seagrass and mangrove diets have been observed by examining the guts of individual green turtles (Brand et al. 1999; Arthur et al. 2009) and may simply reflect the food items available that yield the highest nutritional value with minimal search and handling costs (Bjorndal 1997).

Foraging patterns of adult turtles can be disrupted by reproduction. Appropriate forage is often lacking during long-distance migrations between feeding and breeding grounds (Carr 1975) and at some sites is not available in the vicinity of the nesting beach (e.g., at Tortuguero, Costa Rica and Ascension Island, South Atlantic Ocean). Guts of migrating green turtles captured between seagrass pastures in Nicaragua and the Tortuguero nesting beach contained only small quantities of low grade forage (Mortimer 1982) as did those of nesting females examined at Tortuguero (Meylan 1978), which contained water hyacinth debris and flotsam deposited in the river mouth (Mortimer 1982). At Ascension, the guts of females were empty; while in Northern Cyprus, a nesting area where there is abundant seagrass, females were found to have guts packed with seagrass (Hays et al. 2002). Breeding Ascension turtles sometimes move in to eat refuse dumped from ships or shore (Carr et al. 1974) suggesting that their fast may not be voluntary. At Raine Island Australia, analysis of the gut contents of 101 nesting females killed on shore by heat stress found that $60 \%$ of the guts were completely empty, and the remainder showed evidence of only intermittent foraging, mostly on calcareous algae and animal matter including sea anemones and jellyfish (Tucker and Read 2001). The authors did not describe availability of forage near Raine Island, so it is unclear whether the restricted food intake was determined by habitat, or as Bjorndal (1997) suggests, that occupation of visceral space by female reproductive tissues may preclude or limit continuous feeding. To date, however, no published studies have evaluated the feeding behaviour of both breeding males and females at nesting sites where abundant forage was available.

Here, we investigate green turtle foraging ecology at three Western Indian Ocean coral reef atolls in the Republic of Seychelles, in the context of what is known globally about the diet of immature and adult green turtles (Esteban et al. 2019 Mar Biol in review). Specifically, we (1) examine green turtle gut contents (oesophagus and stomach) from adult male turtles and breeding and non-breeding females, and we compare the amount and relative importance of food items encountered; (2) examine the oesophageal contents of 8 otherwise apparently healthy immature green turtles found dead at Desroches atoll; and (3) assess the habitat at locations where adult turtles were captured in 1982-1983 and which satellite tracking later identified as green turtle foraging habitat in 2016. By combining these results, the study will improve knowledge of green turtle habitat requirements in the Western Indian Ocean to help guide regional conservation management.

\section{Materials and methods}

\section{Study site and sample collection}

This study focuses on the diet composition of green turtles at three sites (Cosmoledo, Farquhar and Desroches atolls) 
(Fig. 1) in the outer islands of the Republic of Seychelles. All three atolls host the following life stages of green turtles: adult males and females that mate and lay eggs at the atolls (Mortimer 1984); adult females that nest at distant sites but use the atoll as adult foraging habitat during intervals between nesting seasons (Bourjea et al. 2015; Christiansen et al. 2017; GC Hays and N Esteban unpubl data); and immature and subadult turtles ( $>35 \mathrm{~cm}$ carapace length) that use the atoll as developmental habitat. The atolls probably also provide adult foraging habitat for males that breed at distant sites, but this is not yet confirmed. All three atolls feature expanses of seagrass habitat inside and outside their fringing reefs. These are dominated by the following species: Cosmoledo, Thalassodendron ciliatum, Thalassia hemprichii, Cymodocea rotundata, and Cymodocea serrulata; Farquhar, T. ciliatum and T. hemprichii; and Desroches, T. ciliatum, T. hemprichii, and Halophila ovalis, as well as Syringodium isoetifolium (Kalugina-Gutnik et al. 1992; JA Mortimer and M Morgan unpubl data). Associations of seagrass and macroalgae occur, the most common involving the calcareous algae, Halimeda spp (see Kalugina-Gutnik et al. 1992 for descriptions and list of species).

During 1982-1983, green turtles were hunted at Cosmoledo and Farquhar atolls for human consumption. Adult males were legally harpooned at sea, usually within or just beyond the reef crest of the atoll. Some males were kept alive and transported $(\sim 800-1100 \mathrm{~km})$ to the human population centres of the Inner Islands, while others were slaughtered on site and their meat was salted (Mortimer 1984). In addition, nesting females whose fatty meat was considered superior to that of the males were occasionally taken (illegally) from the nesting beach for local consumption. No turtles were killed specifically to provide samples for this study.

The digestive tract of each turtle was dissected on site after slaughter and all food items were removed from the oesophagus and upper cardiac region of the stomach at the point where food had not yet been modified by digestion (defined as gut throughout this study). In all, 46 samples (Cosmoledo, $n=12$; Farquhar, $n=34$ ) were collected along with the following data: location of capture (marked on Admiralty Chart), CCL (cm), and sex (Table 1). All the males were adults with long tails (Mortimer 1984) and many of them had been harpooned while mating. Reproductive (gravid) females were identified by ovarian follicles $>2 \mathrm{~cm}$ (Owens 1980), but most breeding females were captured on the nesting beach. The samples were initially fixed in 5\% formalin in sea water for $24 \mathrm{~h}$ and subsequently transferred to $70 \%$ ethanol for preservation before analysis. An absence of indeterminate slurry suggests that our samples were well preserved despite their long storage.

During 2016-2018, at Desroches atoll, Island Conservation Society (ICS) personnel collected gut content samples from dead immature green turtles stranded on the beach $(n=8)$. They all appeared to be in good health prior to stranding and their guts were packed full of food (seagrass). Cause of death is unknown but may have resulted from drowning subsequent to entanglement in fishing gear. CCL was measured and a small food sample from a single point
Fig. 1 The location of study sites: a Location of Republic of Seychelles in the Western Indian Ocean. b Three atolls (indicated by red dots) within the Seychelles Exclusive Economic Zone (shown in white) where samples were collected. c Comparison of capture locations of green turtles sampled in 1982-1983 (red open circles) with Fastloc-GPS locations (black open circles) indicating core feeding sites (within and outside of the atoll rim) of post-nesting female green turtle satellite tracked from Diego Garcia atoll in Chagos Archipelago (location shown on Fig. 1a) to Farquhar atoll (location indicated by black box on Fig. 1b) in 2015-2016 Bathymetry map source: Esri, DeLorme, GEBCO, NOAA NGDC, and other contributors

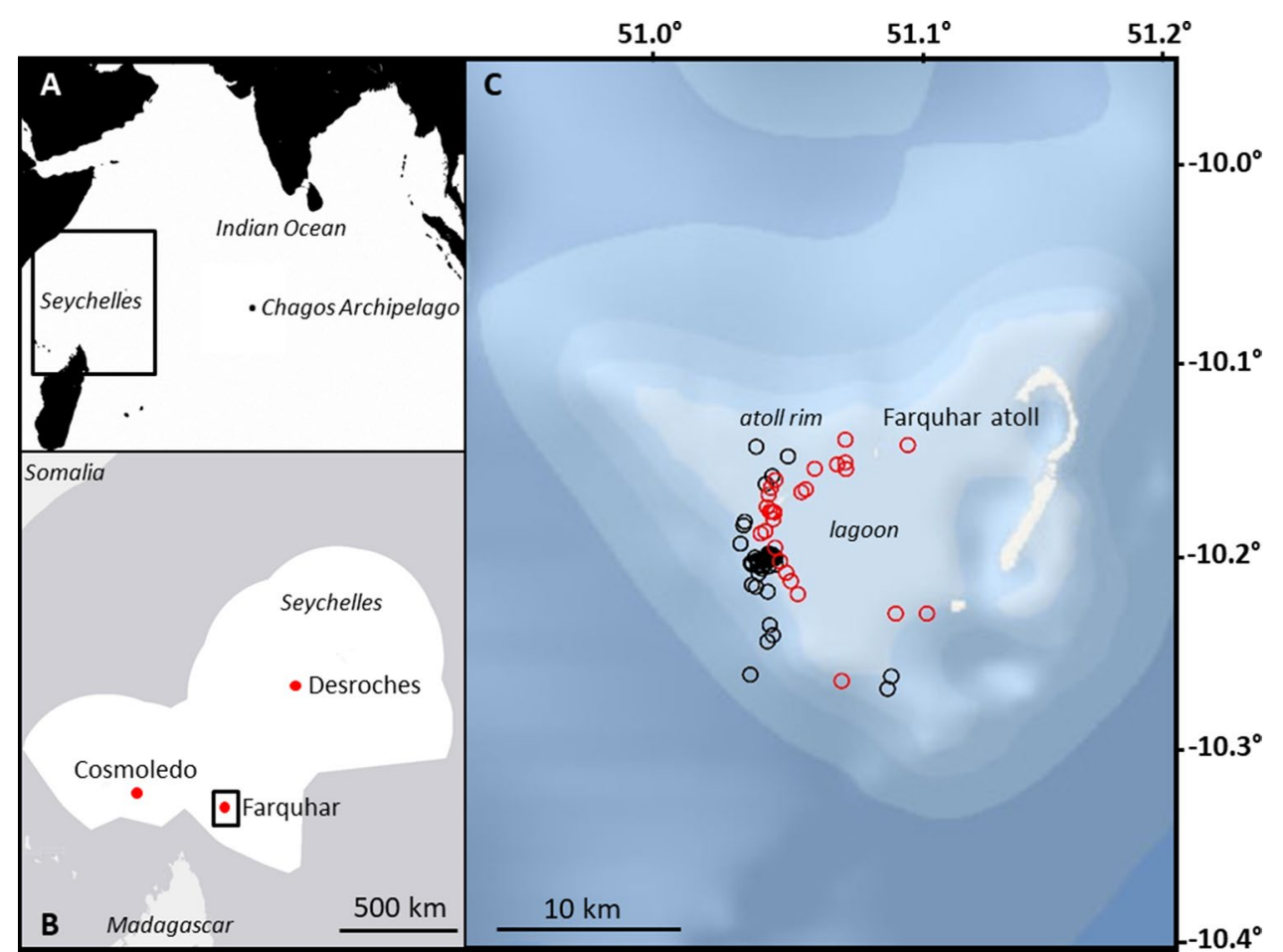


Table 1 Capture dates, locations and details (number, size, sex) of green turtles harvested in Republic of Seychelles

\begin{tabular}{|c|c|c|c|c|c|c|c|}
\hline \multirow[t]{2}{*}{ Location } & \multirow[t]{2}{*}{ Latitude and Longitude } & \multirow[t]{2}{*}{ Dates sampled } & \multicolumn{3}{|c|}{ Number } & \multirow{2}{*}{$\begin{array}{l}\text { Size Range } \\
(\mathrm{CCL}, \mathrm{cm})\end{array}$} & \multirow[t]{2}{*}{ Mean \pm SE $(\mathrm{cm})$} \\
\hline & & & $\mathrm{M}$ & $\mathrm{F}$ & $\mathrm{U}$ & & \\
\hline Cosmoledo & $9.7088^{\circ} \mathrm{S} 47.5153^{\circ} \mathrm{E}$ & 19 Jan-25 May 1982 & 4 & 8 & - & $93-117$ & $109 \pm 2.19$ \\
\hline Farquhar & $10.1881^{\circ} \mathrm{S} 51.1566^{\circ} \mathrm{E}$ & 10 May-7 Oct 1983 & 23 & 10 & 1 & $72-115$ & $103 \pm 1.28$ \\
\hline Desroches & $5.6912^{\circ} \mathrm{S} 53.6671^{\circ} \mathrm{E}$ & Jan 2016-Jan 2018 & - & - & 8 & $48.5-71$ & $63 \pm 2.44$ \\
\hline
\end{tabular}

$M$ male, $F$ female, $U$ unknown; immature along the full oesophagus was collected from each, frozen, and stored in $70 \%$ ethanol prior to analysis.

\section{Diet analysis}

Processing and identification of samples took place at Swansea University. Samples were filtered, blotted dry, and wet mass measured to the nearest $0.01 \mathrm{~g}$. The $1982-1983$ Cosmoledo/Farquhar samples were subsampled, but the 2016-2018 Desroches samples were analysed fully given their small size. A stratified sub-sampling protocol was followed to ensure representation of the whole sample: (1) large items were removed from sample for identification, (2) the remaining sample was mixed, spread out evenly and split into 10 equal subsamples in a gridded tray, (3) a random number generator was used to randomly select each subsample for analysis to reduce bias, (4) for the first five samples, $50 \%$ of the sample was analysed, $10 \%$ at a time. No new dietary items were found after identifying specimens in the first two $10 \%$ subsamples. Remaining samples: two subsamples were analysed (20\% of the original sample size).

Within each gut sample, dietary items were identified to the lowest taxonomic level using a dissecting microscope (Olympus SZX61, 0.7-11.5x with an SDF PLAPO 1XPF objective lens) and available identification guides, literature and websites (Lanyon 1986; Kalugina-Gutnik et al. 1992; Waycott et al. 2004; WILD Singapore, 2016). To gain a positive identification of sponges, a small fragment was dissolved in sodium hypochlorite (NaOCI) to check for the presence of spicules. Photomicrographs were taken of all dietary items (Olympus UC30 3.2 Microscope Digital Camera attachment; Olympus cellSens imaging software) for subsequent verification of species. Dry mass of each taxon was weighed to the nearest $0.1 \mathrm{mg}$ after oven drying for $24 \mathrm{~h}$ at $40{ }^{\circ} \mathrm{C}$.

\section{Identifying and ground-truthing foraging locations at Farquhar Atoll}

Two sets of data were used to identify green turtle foraging locations at Farquhar atoll. The first entailed recording onto Admiralty Charts the locations where 27 green turtles were captured in 1982-1983 and then transferring those points to Google Earth. The second comprised day-time surfacing locations of a green turtle that had been equipped with a Fastloc-GPS Argos satellite tag after nesting on the island of Diego Garcia $\left(7.42^{\circ} \mathrm{S}, 72.45^{\circ} \mathrm{E}\right)$ in the Chagos Archipelago (Esteban et al. 2017), and then tracked to its foraging grounds at Farquhar in 2016 (Fig. 1a, b). FastlocGPS locations obtained from 4 or more satellites and with residual values of $<35$ were examined (see Dujon et al. 2014 for a description of Fastloc-GPS accuracy). The tracking data were analysed using ArcGIS 10.3 to identify locations ( $n=98)$ visited during local daytime [i.e., those positions recorded between 0900 and $1700 \mathrm{~h}$ local time (UTC $+4 \mathrm{~h})]$.

During March 2016 and March 2018, as many of the daytime Fastloc-GPS location points as possible were surveyed to assess benthic habitats. On 25 March 2016, 14 points situated outside the rim of the atoll were assessed in terms of depth and visible characteristics of the benthos, using a glass-bottomed bucket and the fathometer built into the small research skiff. Two years later, on 22-23 March 2018, benthic habitat at a sub-sample of Fastloc-GPS daytime locations $(n=15)$, this time inside the lagoon, was ground-truthed and benthic features of the seagrass habitats were recorded using Seagrass-Watch monitoring protocols (www.seagrasswatch. org) for a distance of at least $20 \mathrm{~m}$ from each location. Substrate type was assessed by placing quadrats $\left(0.25 \mathrm{~m}^{2} ; n=52\right.$, mean $=3.47$ quadrats, range $=1-5$ per site) at intervals of at least $10 \mathrm{~m}$ apart (estimated using fin kicks) and recording relative cover of broad benthic groups (seagrass, hard coral, soft coral, sponge, macroalgae, rock, rubble, dead coral, sand) and species composition. Care was taken to search under the seagrass canopy for any additional species. Depths at those sites were measured from the boat using a hand-held depth finder (HawkEye DT1H). Separate qualitative surveys of seagrass habitat were also conducted at various points around the inside of the lagoon to determine what other seagrass species and habitats occur at Farquhar.

\section{Data analysis}

Univariate analyses were performed in $\mathrm{R}$ version 3.3.3 ( $\mathrm{R}$ Core Team 2017). To understand the relative importance of various species in the diet, the percent frequency of occurrence, percent biomass and an Index of Relative Importance (IRI) were calculated for each diet item/species (see von Brandis et al. 2014 for equation). 
To account for differences in gut fullness, the biomass of diet species was standardised. Diet items/species biomass $\%$ by location, sex, and breeding status (of females based on status of the ovaries) were presented using the ggplot2 package (Wickham 2016). All means are presented with \pm 1 SE. We conducted analysis of differences in green turtle diet composition by sex, breeding status and location using a two-way nested ANOSIM in Primer v7 (Clarke and Warwick 1994).

Diet composition data (percentages based on biomass) were arcsine-square-root-transformed for analysis. A Mann-Whitney $U$ was used to investigate the difference between the biomass of seagrass consumed by "gravid females" and by "males and non-breeding females". A oneway ANOVA was used to investigate the difference in gut weight between "gravid females", "non-breeding females" and "males". The Tukey test was used to compare mean gut content wet weight of males, gravid females, and nonbreeding females.

\section{Results}

\section{Diet analysis}

Green turtle diet was primarily plant based in the Seychelles. At Cosmoledo and Farquhar atolls, seagrass represented an average of $81 \%$ of the diet $(\mathrm{SE}=4 \% ; n=46)$. In 37 individuals (80.4\%) seagrass, mostly Thalassodendron ciliatum, dominated; in 1 turtle $(2.2 \%)$ macroalgae dominated; and 8 turtles $(17.4 \%)$ were characterised by mixed diets. No significant difference $(p=0.605)$ was evident between the diets of males $(n=26)$ and non-breeding females $(n=2)$; so, data for these two groups were pooled for subsequent analysis. The diet of non-breeding females was not considered separately due to the low sample size.
Dietary items were categorised into 8 dietary component groups: seagrass, macroalgae, sponges, bryozoans, cnidarians (mostly epiphytic), miscellaneous invertebrates, substrate, and marine debris (Table 2). Seagrass accounted for the biomass of almost all of the gut contents analysed of adult males and non-breeding females $(95 \pm 2 \%$; mean $\pm \mathrm{SE} ; n=28)$, but only $58 \pm 8 \%($ mean $\pm \mathrm{SE} ; n=17)$ of the diet of gravid breeding females (Fig. 3a, Table 2). This difference was statistically significant (Mann-Whitney $U$ test, $U=62, N 1=28, N 2=17, p<0.0001)$. When adult males $(n=26)$ and non-breeding females $(n=2)$ were considered separately, seagrass accounted for $95 \pm 2 \%$ and $100 \pm 0 \%$ (mean $\pm \mathrm{SE}$ ) of the diet, respectively. In contrast, the gravid female diet included relatively large amounts of substrate $(14 \pm 5 \%$; mean $\pm \mathrm{SE})$ and macroalgae $(13 \pm 3 \%$; mean $\pm \mathrm{SE})$. Halimeda spp were disproportionately abundant $(35 \%)$ in gravid females $(n=6)$, but absent from the guts of adult males and non-breeding females. Cnidarians (mainly epiphytic hydrozoans) and sponges occurred frequently but with low biomass across all turtle groups.

In terms of frequency of occurrence, seagrass was encountered in all turtles $(100 \%)$. In male and non-breeding females, epiphytic cnidarians (75\%), macroalgae (43\%), sponge (39\%), and marine debris (32\%) were all ingested frequently, with other dietary components less so. In the diet of gravid females, most dietary components occurred with relatively high frequency: macroalgae $(82 \%)$, sponges $(82 \%)$, substrate $(71 \%)$, bryozoans $(65 \%)$, cnidarians $(41 \%)$ and marine debris $(35 \%)$.

The IRI of dietary items included 26 dietary items: 15 at Cosmoledo, 25 at Farquhar and 7 at Desroches (Table 3). Seagrass was the most important dietary item at all sites and amongst all groups of turtles. This was mostly T. ciliatum but in some cases T. hemprichii. Small amounts of Halodule uninervis and Halophila stipulacea
Table 2 Key diet composition of male and non-breeding female $(n=28)$ and gravid female $(n=17)$ green turtles in Seychelles. Frequency of occurrence (FO) of dietary components present in turtles (1982-1983) and relative biomass of dietary components found in the gut contents

\begin{tabular}{|c|c|c|c|c|c|c|c|c|c|c|}
\hline \multirow[t]{3}{*}{ Diet groups } & \multicolumn{5}{|c|}{ Male and non-breeding female } & \multicolumn{5}{|c|}{ Gravid female } \\
\hline & \multirow[t]{2}{*}{$\mathrm{FO}$} & \multicolumn{4}{|c|}{ Relative proportion of biomass } & \multirow[t]{2}{*}{$\mathrm{FO}$} & \multicolumn{4}{|c|}{ Relative proportion of biomass } \\
\hline & & Mean & $\pm \mathrm{SE}$ & Min & $\operatorname{Max}$ & & Mean & $\pm \mathrm{SE}$ & Min & $\operatorname{Max}$ \\
\hline Seagrasses & 100 & 95 & 2 & 40 & 100 & 100 & 58 & 8 & 1 & 100 \\
\hline Macroalgae & 43 & 2 & 2 & 0 & 57 & 82 & 15 & 3 & 0 & 35 \\
\hline Sponges & 39 & 2 & 1 & 0 & 24 & 82 & 7 & 2 & 0 & 29 \\
\hline Bryozoans & 4 & $*$ & $*$ & 0 & 0 & 65 & 3 & 1 & 0 & 20 \\
\hline Cnidarians & 75 & $*$ & $*$ & 0 & 0 & 41 & $*$ & $*$ & 0 & 2 \\
\hline Invertebrates $^{\mathrm{a}}$ & 7 & $*$ & $*$ & 0 & 1 & 12 & $*$ & $*$ & 0 & 0 \\
\hline Substrate & 4 & $*$ & $*$ & 0 & 0 & 71 & 15 & 6 & 0 & 84 \\
\hline Marine debris ${ }^{\mathrm{b}}$ & 32 & $*$ & $*$ & 0 & 11 & 35 & 1 & 1 & 0 & 19 \\
\hline
\end{tabular}


were also recorded. These results indicate consistency in green turtle diet at three sites separated from each other by 400-825 km in the Western Indian Ocean. Gravid female diets had lower IRI seagrass scores than those of male, non-breeding female, and immature turtles. Halimeda spp featured prominently in the diet of gravid females at Cosmoledo (IRI $=15$ ), while calcium carbonate substrate was prominent in the diet of gravid females at Farquhar $(\mathrm{IRI}=12)$.

Differences in gut content biomass between "breeding females" and "males and non-breeding females" were statistically significant by a two-way nested ANOSIM (global $r=0.569, p<0.01$ ) (Fig. 2). Diet compositions at Cosmoledo and Farquhar were similar (global $r=0, p=0.667$ ). Gravid female gut contents were $53 \%$ less in volume and more varied (seven dietary component groups including macroalgae, calcium carbonate substrate, seagrass) compared to male and non-breeding female guts (only three dietary component groups found $>0.1 \mathrm{mg}$ despite food availability) (Table 2). Wet weights of the gut samples differed significantly (ANOVA, $F_{2,42}=11.51, p<0.001$ ) by sex and female breeding status. Breeding female $(n=17)$ gut biomass was significantly lower than those of males $(p<0.001 ; n=26)$ and non-breeding females ( $p<0.05 ; n=2$ ) (Fig. 2).

Figure 3 compares the contributions made by the eight dietary component groups and by individual species of seagrass to the diets of breeding females, males, and nonbreeding females at Cosmoledo and Farquhar. Seagrass was the most abundant dietary component in all turtle groups (Fig. 3a) and at both sites (Fig. 3c). T. ciliatum was the dominant seagrass in the diets of both males and breeding females, but T. hemprichii was dominant in the diets of nonbreeding females ( $n=2)$ (Fig. 3b).
Table 3 Index of Relative Importance (IRI) of dietary items in gut contents of green turtles captured in 1982-1983 at Cosmoledo atoll (C) $(n=7$ gravid females $(\mathrm{G}) ; n=5$ males and non-breeding females $(\mathrm{O})$ and Farquhar atoll $(\mathrm{F})[n=10$ gravid females $(\mathrm{G}) ; n=23$ males and non-breeding females $(\mathrm{O})$; $n=1$ immature (I)], and in 2016-2018 at Desroches atoll (D) $[n=8$ immature (I) $]$

\begin{tabular}{|c|c|c|c|c|c|c|c|}
\hline \multirow[t]{3}{*}{ Kingdom Phylum } & \multirow[t]{3}{*}{ Genus species } & \multicolumn{6}{|c|}{ IRI (sites) } \\
\hline & & \multicolumn{2}{|l|}{$\overline{\mathrm{C}}$} & \multicolumn{3}{|l|}{$\mathrm{F}$} & \multirow{2}{*}{$\begin{array}{l}\text { D } \\
\text { I }\end{array}$} \\
\hline & & $\mathrm{G}$ & $\mathrm{O}$ & $\mathrm{G}$ & $\mathrm{O}$ & I & \\
\hline \multicolumn{8}{|l|}{ Plantae } \\
\hline \multirow[t]{4}{*}{ Tracheophyta } & Thalassodendron ciliatum & 51 & 40 & 58 & 74 & 88 & 92 \\
\hline & Halodule uninervis & $<1$ & $<1$ & - & - & - & - \\
\hline & Thalassia hemprichii & 4 & 48 & $<1$ & 4 & - & - \\
\hline & Halophila stipulacea & - & - & - & $<1$ & - & - \\
\hline \multirow[t]{3}{*}{ Chlorophyta } & Halimeda spp & 15 & - & $<1$ & - & - & $<1$ \\
\hline & Caulerpa spp & - & - & 2 & $<1$ & 12 & - \\
\hline & Caulerpa serrulata & - & - & $<1$ & - & - & - \\
\hline \multirow[t]{3}{*}{ Rhodophyta } & $x$ & - & - & - & $<1$ & - & - \\
\hline & Hypnea esperi & $<1$ & - & - & $<1$ & - & - \\
\hline & Heterosiphonia spp & - & - & $<1$ & $<1$ & - & - \\
\hline Phaeophyta & Turbinaria $\mathrm{sp}$ & - & - & 1 & - & - & - \\
\hline Macroalgae & $x$ & 3 & - & 1 & 1 & - & $<1$ \\
\hline \multicolumn{8}{|l|}{ Animalia } \\
\hline Sponges & $x$ & 2 & $<1$ & 6 & 1 & - & 4 \\
\hline \multirow[t]{2}{*}{ Cnidaria } & $x$ & - & $<1$ & - & $<1$ & - & - \\
\hline & $x$ & $<1$ & $<1$ & $<1$ & $<1$ & - & - \\
\hline Bryozoa & $x$ & 2 & $<1$ & 1 & - & - & $<1$ \\
\hline Echinodermata & $x$ & $<1$ & - & $<1$ & - & - & - \\
\hline Annelida & $x$ & - & - & - & $<1$ & - & $<1$ \\
\hline \multirow[t]{2}{*}{ Crustacea } & $x$ & - & - & - & $<1$ & - & - \\
\hline & Ocypode cordimanus & - & - & - & $<1$ & - & - \\
\hline Mollusca & $x$ & - & - & - & $<1$ & - & - \\
\hline \multicolumn{8}{|l|}{ Other } \\
\hline Glass & & $<1$ & - & - & $<1$ & - & - \\
\hline Plastic & & $<1$ & $<1$ & $<1$ & $<1$ & $<1$ & - \\
\hline Debris & & - & - & $<1$ & $<1$ & - & - \\
\hline Shell & & $<1$ & - & $<1$ & & - & - \\
\hline Substrate & & 3 & - & 12 & $<1$ & - & $<1$ \\
\hline
\end{tabular}

$x$ unidentified species, - none 


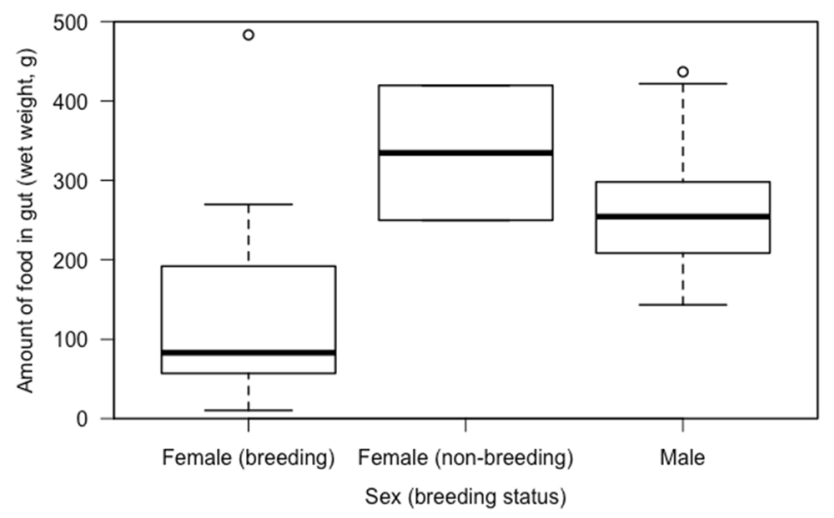

Fig. 2 Comparison of the amount of food found in the guts of breeding females, non-breeding females, and males. Wet weight (g) was recorded for each gut sample. Bold horizontal lines indicate median, boxes delineate upper and lower quartiles and whiskers define range. Outliers are plotted as separate points

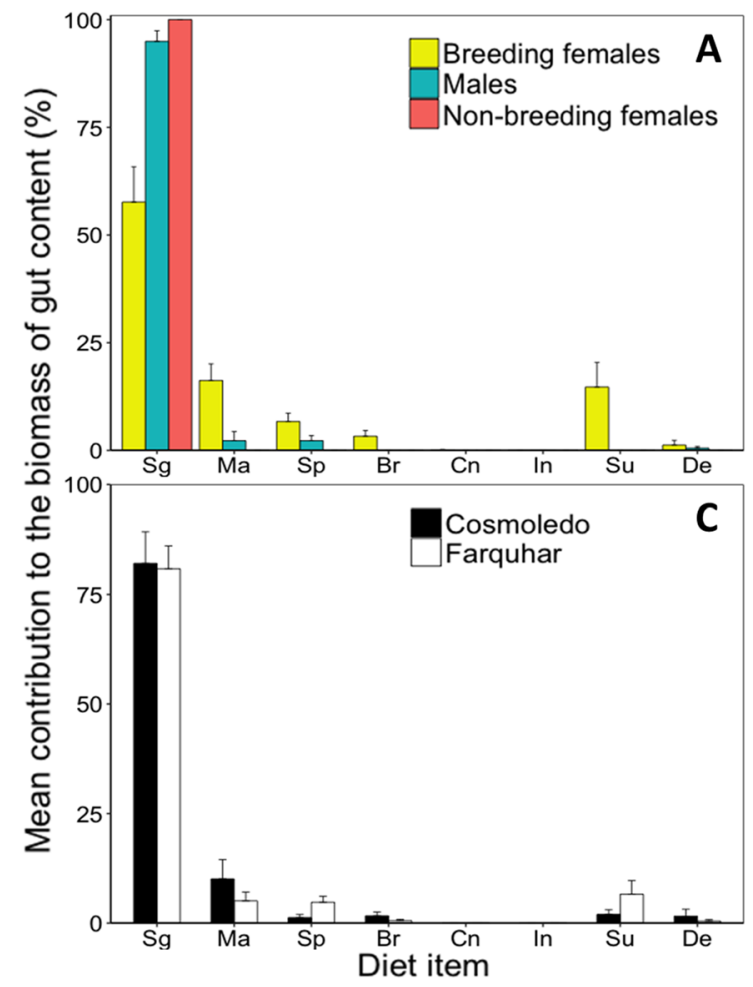

Fig. 3 Comparison of green turtle diets by sex and female breeding status [breeding females (yellow; $n=17$ ); non-breeding females (red; $n=2$ ); males (blue; $n=26$ )] and site [Cosmoledo (black; $n=12$ ); Farquhar (white; $n=34$ )]. Relative contribution of eight dietary component groups by a sex and female breeding status and by $\mathbf{c}$ site. Relative contribution of three seagrass species [Thalassodendron ciliatum $(T c)$, Thalassia hemprichii $(\mathrm{Th})$ and Halodule uninervis $(\mathrm{Hu})]$
In terms of biomass, T. ciliatum was the most abundant seagrass in the guts of turtles at both Farquhar (92\%) and Cosmoledo (76\%), followed by T. hemprichii which was relatively more abundant in guts from Cosmoledo (23\%) than Farquhar (8\%) (Fig. 3d).

\section{Foraging habitat assessment at Farquhar Atoll}

Capture locations of 27 turtles sampled at Farquhar in 1982-1983 are shown by red circles in Fig. 1c. For safety, fishermen rarely operated outside the atoll rim; so, most capture locations are concentrated along the western perimeter of the atoll inside the lagoon, especially near the shallow entrance to the lagoon where turtles (but not boats) can pass at high tide. The daytime locations of the green turtle equipped with a Fastloc-GPS Argos satellite tag are indicated by black circles $(n=99)$ in Fig. 1c. The majority of these locations overlap and are close to the atoll $\operatorname{rim}(n=93)$; whilst only a few locations are at a mean distance of $1.0 \mathrm{~km}$ from the atoll $\operatorname{rim}(\mathrm{SE}=6.44$, range $=0.49-2.58 \mathrm{~km} ; n=6)$. These locations span a range of depths both inside and outside the lagoon. Sites outside the atoll rim, surveyed in
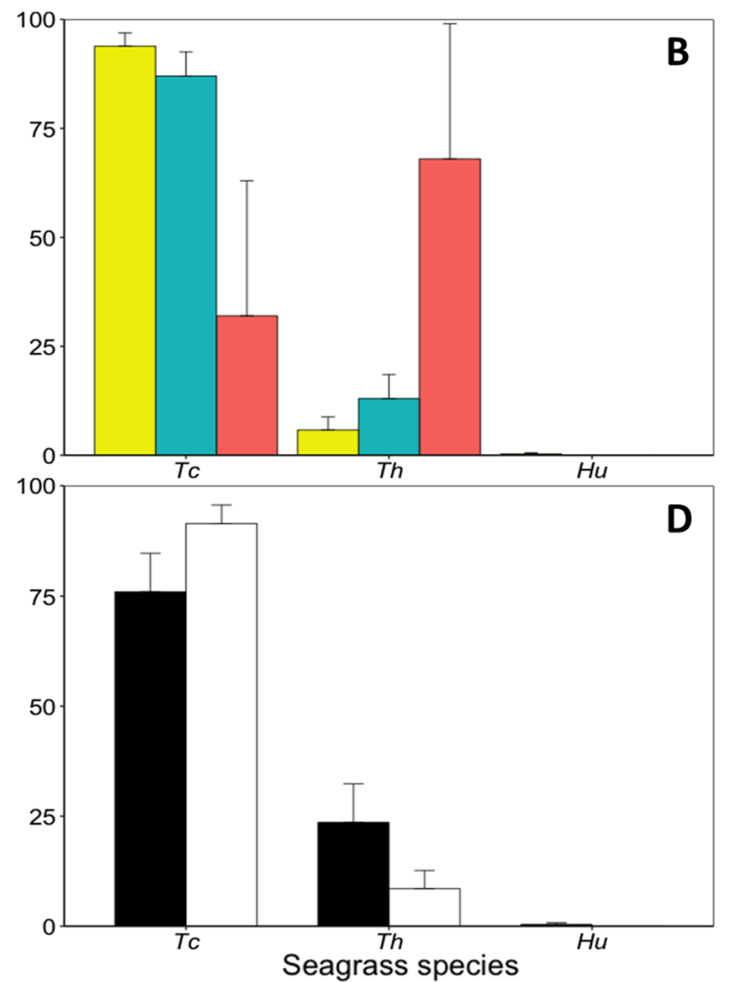

by $\mathbf{b}$ sex and female breeding status and by $\mathbf{d}$ site. Mean values are shown with positive standard error bars. Dietary component groups: seagrasses $(\mathrm{Sg})$, macroalgae (Ma), sponges ( $\mathrm{Sp})$, bryozoans $(\mathrm{Br})$, cnidaria $(\mathrm{Cn})$, invertebrates (In), substrate (Su) and debris (De). Halophila stipulacea not included, as weight of the fragment $(n=1)$ was negligible 
March 2016, were relatively deep $($ mean $=36.6 \mathrm{~m} ; \mathrm{SE}=7.5$; range $=8.8-90.5 \mathrm{~m} ; n=14)$ and, in most cases, the seabed was not visible through the glass-bottomed bucket. Sites within the lagoon, surveyed in March 2018, were generally shallow (mean $=2.7 \mathrm{~m} ; \mathrm{SE}=0.2 ; n=15$ ). Seagrass was present at $100 \%$ of those sites with a high mean seagrass cover $(76.9 \% ; \mathrm{SE}=3.9 ; n=13)$. $T$. ciliatum was the only seagrass species recorded, with a mean canopy height of $25.8 \mathrm{~cm}(\mathrm{SE}=1.3)$. Macroalgae were recorded at only four sites (mean cover $=0.7 \%$; $\mathrm{SE}=0.5 ; n=14$ ). Substrate colonised by seagrass included rocks, rubble, dead coral, sponge and sand. Seagrass communities observed elsewhere around the Farquhar lagoon were also dominated by T. ciliatum, but included small patches of $T$. hemprichii, which in most cases appeared to have been cropped by turtles.

\section{Discussion}

At sites in the Republic of Seychelles, we report an almost exclusive diet of seagrass for green turtles. Seagrass biomass represented $95 \%$ of the diet of the adults sampled in our study $(n=28)$, excluding the gravid females $(n=17)$. This figure is amongst the highest reported in the world (Esteban et al. 2019 Mar Biol in review). All countries in the Western Indian Ocean host extensive seagrass meadows (Gullström et al. 2002); so, it is likely that seagrass is an important diet component for green turtles throughout this largely understudied region. Other comparable sites in the Western Indian Ocean, where seagrass exceeds $90 \%$ of the diet, include the United Arab Emirates (Hasbún et al. 2000), Yemen (Hirth et al. 1973) and Aldabra atoll in Seychelles (Frazier 1971). A high prevalence of seagrass has also been reported in Oman (Ross 1985). These findings have been supported by recent studies in Mayotte, Western Indian Ocean where green turtles graze on an assemblage of eight seagrass species commonly found there (Ballorain et al. 2010).

The most abundant seagrass species recorded in the guts of the Seychelles turtles at Cosmoledo, Farquhar and Desroches atolls were T. ciliatum and T. hemprichii, which is not surprising as these were the dominant seagrass species recorded at those sites by Kalugina-Gutnik et al. (1992). T. ciliatum is particularly abundant in the outer islands of Seychelles, forming extensive monospecific meadows, especially in deeper localities on sandy bottoms, coral reefs and sand-covered rocks (Short et al. 2010). Early studies of green turtles at Aldabra atoll in Seychelles recorded $T$. ciliatum as the primary diet component along with small amounts of T. hemprichii and macroalgae (Frazier 1971). The importance of different seagrass species for green turtle diet in Farquhar atoll suggests a relative preference for $T$. hemprichii (over T. ciliatum) given its scarcity in seagrass habitats (current study). Although T. ciliatum formed the bulk of the turtle diet, anecdotal accounts from Seychellois turtle hunters (Mortimer, pers comm) indicate that turtles prefer other seagrass species if they are available. Neutral Detergent Fibre (NDF) is a measurement of most structural components in plant cells and it is possible that NDF in $T$. ciliatum is higher than other seagrasses, indicating increased difficulty for digestion, although data for $T$. ciliatum are not available (Trevathan-Tackett et al. 2017). Elsewhere in the Western Indian Ocean, the importance of T. ciliatum to the diet is variable: at Mayotte it does not feature prominently in the diet (Ballorain et al. 2010); while green turtles certainly forage on T. ciliatum in the monospecific seagrass meadows in the Great Chagos Bank (Esteban et al. 2018).

It is noteworthy that some daytime locations for tracked turtles were deep, being up to $90 \mathrm{~m}$. The foraging site in Farquhar atoll is in the vicinity of a very steep drop-off $(<1 \mathrm{~km}$ between atoll rim and $500 \mathrm{~m}$ depth; Stoddart and Poore 1970) which is a relatively small area for a proficient swimmer with daytime home ranges of $19 \mathrm{~km}^{2}$ (95\% KUD, $\mathrm{SD}=15.78, n=6$ ) in the Seychelles (Christiansen et al. 2017). Likewise, we have shown previously that turtles forage in relatively deep areas on the Great Chagos Bank $(29 \mathrm{~m})$ where in situ surveys with divers and drop-down cameras have confirmed extensive seagrass beds (Esteban et al. 2018). Taken together, these findings add to the growing evidence that, in the Indian Ocean, seagrass may be found much deeper than previously assumed. In support of this conclusion, Kalugina-Gutnik et al. (1992) used SCUBA to survey distribution of seagrass and macroalgae in the Seychelles, and reported seagrass growing to depths of $37 \mathrm{~m}$; and, on the Saya de Malha Bank, the EAF-Nansen Leg 2.1 (May 2018) expedition also recorded T. ciliatum at $37 \mathrm{~m}$ and Halophila decipiens at $70 \mathrm{~m}$ (Sundy Ramah, pers. comm.). We report that foraging sites of one satellite tracked individual in areas of extensive nearly monospecific beds of $T$. ciliatum in 2016 coincided with capture locations of $>75 \%$ of turtles captured in 1983, indicating long-term health of seagrass habitat in Farquhar atoll but possibly underrepresenting the overall foraging habitat size and distribution around the atoll.

Our regional case study presents evidence that the diet of gravid females differs from that of adult males (breeding and non-breeding) and non-breeding females. We present the first findings that compare the diets of breeding males and gravid female green turtles at sites where abundant benthic forage occurs adjacent to nesting beaches. Previous studies that recorded relatively empty guts and low-quality diets of gravid female green turtles (Carr et al. 1974; Mortimer 1982; Tucker and Read 2001) did not confirm whether reproductive status or forage availability caused the females to fast. At both Cosmoledo and Farquhar, the food present in the gut of gravid females weighed significantly less and was also more variable than that of both adult males and 
non-breeding females. Due to the low sample size of nonbreeding females, this observation clearly deserves further investigation.

We conclude that the restricted and unusual diets of gravid female green turtles are not driven by forage availability but more likely by a combination of other factors. During the inter-nesting period, green turtles often exhibit restricted movements between clutch depositions (Esteban et al. 2017). It may be that resting and conserving energy in locations inaccessible to the unwanted attentions of courting males and predators while the next egg clutch matures may be more important than foraging. It may also be that the maturing clutches of eggs take up so much volume inside a turtle that there is no room for a full gut. Clutch size scales with body size in sea turtles, suggesting that sea turtles lay the largest clutch of eggs they can fit inside their bodies (Hays and Speakman 1991). Another possibility is that gravid females have peculiar dietary needs. The guts of males and non-breeding females foraging on the seagrass flats of Nicaragua (Mortimer 1981) and those of adult males and non-breeding females in the present study contained little or no calcareous matter. In contrast, relatively large amounts of calcareous material (including the calcareous algae (Halimeda spp.), and/or calcareous substrates) were ingested by gravid females in the present study and at Raine Island (Tucker and Read 2001), by gravid green turtles migrating to the Tortuguero nesting grounds (Mortimer 1981, 1982), by gravid hawksbill turtles (Eretmochelys imbricata) in the Caribbean (Meylan 1984) and by gravid desert tortoises (Gopherus agassizii) (Marlow and Tollestrup 1982). Tucker and Read (2001) hypothesised that ingested calcareous material might supply calcium for eggshells, restore depleted calcium reserves in breeding females, or neutralise stomach acid in fasting animals. This explanation is reasonable given that gravid female green turtles may lay up to ten egg clutches at two-week intervals during a single nesting season (Esteban et al. 2017) and the eggs of each clutch need to be shelled on site just prior to being laid. Given the upward trends in green turtle populations in the Western Indian Ocean, there is a need to conserve and monitor seagrass habitats in the context of changing green turtle population densities. Green turtle foraging locations can be indicators of healthy ecosystems that warrant inclusion in MPA proposals (Scott et al. 2012). The Republic of Seychelles is currently developing a comprehensive Marine Spatial Plan (Government of Seychelles 2017) and has committed protection for up to $30 \%$ of its territorial waters to ensure representative species and habitats have long-term protection to improve resilience of coastal ecosystems in a changing climate. Cosmoledo, Farquhar and Desroches atolls all feature prominently in this zoning plan. In the samples we analysed from the Seychelles, it is noteworthy that while the proportion of seagrass in the diet varied across individuals, all individuals had consumed at least some seagrass. This observation adds support for the use of green turtles as indicators of seagrass habitats, reiterating the value of remotely tracking green turtles to help identify hitherto unknown seagrass beds (Hays et al. 2018). Finally, regional satellite tracking studies (Hays et al. 2010, 2014; Bourjea et al. 2015; Christiansen et al. 2017) combined with green turtle foraging ecology studies help resource managers to identify critical habitats in need of long-term protection and enable a better understanding of foraging hotspots and regional connectivity.

Acknowledgements This work was supported by the Bertarelli Foundation as part of the Bertarelli Programme in Marine Science. We thank Islands Development Company (IDC), Government of Seychelles, and WWF-IUCN Project 1809 for support of JAM in Seychelles during 1981-1984 (special thanks: Glenny Savy and Mazarin Constance). Island Conservation Society (ICS) and IDC enabled collection of gut samples at Desroches atoll (special thanks: Jo Bluemel, Matthew Morgan, their teams, and Adrian Skerrett). The 4th ICS/Pangaea Scientific Expedition enabled validation surveys of foraging sites at Farquhar in 2016 with assistance from captain and crew of MV Pangaea, Pierre-André Adam and Josep (Pep) Nogués. Thanks to ICS, IDC, and GEF-UNDP OIP for enabling the seagrass surveys at Farquhar in 2018 (especially Thomas Collier and Licia Calabrese). We are grateful for technical laboratory support provided by Ross Davies and Sam Rees. We thank all volunteers and staff that supported GCH and NE in Diego Garcia, British Indian Ocean Territory. We acknowledge and thank the BIOT Administration for assistance and permission for research to satellite track green turtles in the Chagos Archipelago. HJS was supported with MSc scholarships from Swansea Council and Swansea University. We also thank Dr Jeffrey Seminoff and an anonymous reviewer for their constructive suggestions to improve the manuscript.

Author contributions NE, JAM and GCH conceived the study. JAM led all fieldwork in Seychelles. GCH and NE carried out the satellite tracking study in 2015-16. HJS carried out all laboratory analysis with input from NE, RFKU and JAM. HJS led the data analysis with contributions from all authors. HJS, JAM and NE led the writing of the manuscript with contributions from all authors.

Funding Work by JAM in 1981-1984 was supported by IDC, Government of Seychelles, and WWF-IUCN Project 1809 for support of JAM in Seychelles during 1981-1984. Green turtle Argos-linked FastlocGPS tracking data were supported by a grant to GCH from the Darwin Initiative Challenge Fund grant (EIDCF008), the Department of the Environment Food and Rural Affairs (DEFRA) and financial assistance from the Foreign and Commonwealth Office (FCO) and College of Science of Swansea University. HJS was supported with MSc scholarships from Swansea Council and Swansea University. This work was supported by the Bertarelli Foundation as part of the Bertarelli Programme in Marine Science (BPMS-2017-4).

\section{Compliance with ethical standards}

Conflict of interest The authors declare that they have no conflict of interest.

Ethical approval In the Seychelles, no turtles were killed specifically to provide samples for this study. Permits for attachment of transmitters to green turtles in the Chagos Archipelago were issued by the Commissioner for the British Indian Ocean Territory (BIOT). Fieldwork was 
approved by the Swansea University Ethics Committee and the BIOT Scientific Advisory Group (SAG) of the FCO.

Open Access This article is distributed under the terms of the Creative Commons Attribution 4.0 International License (http://creativeco mmons.org/licenses/by/4.0/), which permits unrestricted use, distribution, and reproduction in any medium, provided you give appropriate credit to the original author(s) and the source, provide a link to the Creative Commons license, and indicate if changes were made.

\section{References}

Ahasan MS, Waltzek TB, Huerlimann R, Ariel E (2017) Faecal bacterial communities of wild-captured and stranded green turtles (Chelonia mydas) on the great barrier reef. FEMS Microbiol Ecol 93:fix139. https://doi.org/10.1093/femsec/fix139

Amorocho DF, Reina RD (2007) Feeding ecology of the East Pacific green sea turtle Chelonia mydas agassizii at Gorgona National Park, Colombia. Endang Species Res 3:43-51. https://doi. org/10.3354/esr003043

Arthur KE, McMahon KM, Limpus CJ, Dennison WC (2009) Feeding ecology of green turtles (Chelonia mydas) from Shoalwater Bay, Australia. Mar Turtle Newsl 123:6-12

Ballorain K, Ciccione S, Bourjea J, Grizel H, Enstipp M (2010) Habitat use of a multispecific seagrass meadow by green turtles Chelonia mydas at Mayotte Island. Mar Biol 157:2581-2590. https://doi. org/10.1007/s00227-010-1520-7

Bjorndal KA (1980) Nutrition and grazing behavior of the green turtle Chelonia mydas. Mar Biol 56:147-154. https://doi.org/10.1007/ BF00397131

Bjorndal KA (1997) Foraging ecology and nutrition of sea turtles. In: Lutz PL, Musick JA (eds) The biology of sea turtles, vol I. CRC Press, Boca Raton, pp 199-232

Bjorndal KA, Suganuma H, Bolten AB (1991) Digestive fermentation in green turtles, Chelonia mydas, feeding on algae. Bull Mar Sci 48:166-171

Bourjea J, Frappier J, Quillard M, Ciccione S, Roos D, Hughes G, Grizel H (2007) Mayotte Island: another important green turtle nesting site in the southwest Indian Ocean. Endang Species Res $3: 273-282$

Bourjea J, Mortimer JA, Garnier J, Okemwa G, Godley BJ, Hughes G, Dalleau M, Jean C, Ciccione S, Muths D (2015) Population structure enhances perspectives on regional management of the western Indian Ocean green turtle. Conserv Genet 16:1069-1083. https://doi.org/10.1007/s10592-015-0723-3

Brand SJ, Lanyon JM, Limpus CJ (1999) Digesta composition and retention times in wild immature green turtles, Chelonia mydas: a preliminary investigation. Mar Freshw Res 50:145-147. https ://doi.org/10.1071/MF98033

Broderick A, Patricio A (2019) Chelonia mydas South Atlantic subpopulation. The IUCN Red List of Threatened Species 2019: e.T142121866A142086337. http://dx.doi.org/10.2305/IUCN. UK.2019-2.RLTS.T142121866A142086337.en. Accessed 30 Aug 2019

Burgett CM, Burkholder DA, Coates KA, Fourqurean VL, Kenworthy WJ, Manuel SA, Outerbridge ME, Fourqurean JW (2018) Ontogenetic diet shifts of green sea turtles (Chelonia mydas) in a mid-ocean developmental habitat. Mar Biol 165:33. https://doi. org/10.1007/s00227-018-3290-6

Burkholder DA, Heithaus MR, Thomson JA, Fourqurean JW (2011) Diversity in trophic interactions of green sea turtles Chelonia mydas on a relatively pristine coastal foraging ground. Mar Ecol Prog Ser 439:277-293. https://doi.org/10.3354/meps09313

Campos P, Guivernau M, Prenafeta-Boldú FX, Cardona L (2018) Fast acquisition of a polysaccharide fermenting gut microbiome by juvenile green turtles Chelonia mydas after settlement in coastal habitats. Microbiome 6:69. https://doi.org/10.1186/ s40168-018-0454-z

Cardona L, Campos P, Levy Y, Demetropoulos A, Margaritoulis D (2010) Asynchrony between dietary and nutritional shifts during the ontogeny of green turtles (Chelonia mydas) in the Mediterranean. J Exp Mar Biol Ecol 393:83-89

Carr A (1975) The Ascension island green turtle colony. Copeia 1975:547-555. https://doi.org/10.2307/1443656

Carr A, Ross P, Carr S (1974) Internesting behaviour of the green turtle, Chelonia mydas, at a mid-ocean island breeding ground. Copeia 1974:703-706. https://doi.org/10.2307/1442684

Chaloupka MY, Pilcher NJ (2019) Chelonia mydas Hawaiian subpopulation. The IUCN Red List of Threatened Species 2019: e.T16285718A142098300. http://dx.doi.org/10.2305/IUCN. UK.2019-2.RLTS.T16285718A142098300.en. Downloaded on 30 August 2019

Chaloupka M, Bjorndal KA, Balazs GH, Bolten AB, Ehrhart LM, Limpus CJ, Suganuma H, Troëng S, Yamaguchi M (2008) Encouraging outlook for recovery of a once severely exploited marine megaherbivore. Glob Ecol Biogeogr 17:297-304. https://doi.org /10.1111/j.1466-8238.2007.00367.x

Christianen MJ, Govers LL, Bouma TJ, Kiswara W, Roelofs JG, Lamers LP, van Katwijk MM (2012) Marine megaherbivore grazing may increase seagrass tolerance to high nutrient loads. J Ecol 100:546-560. https://doi.org/10.1111/j.1365-2745.2011.01900.x

Christiansen F, Esteban N, Mortimer JA, Dujon AM, Hays GC (2017) Diel and seasonal patterns in activity and home range size of green turtles on their foraging grounds revealed by extended Fastloc-GPS tracking. Mar Biol 164:10. https://doi.org/10.1007/ s00227-016-3048-y

Clarke KR, Warwick RM (1994) Change in marine communities: an approach to statistical analysis and interpretation. Plymouth Marine Laboratory, Plymouth

Coleman FC, Williams SL (2002) Overexploiting marine ecosystem engineers: potential consequences for biodiversity. Trends Ecol Evol 17:40-44. https://doi.org/10.1016/S0169-5347(01)02330-8

Dujon AM, Lindstrom RT, Hays G (2014) The accuracy of FastlocGPS locations and implications for animal tracking. Methods Ecol Evol 5:1162-1169. https://doi.org/10.1111/2041-210X.12286

Esteban N, Mortimer JA, Hays GC (2017) How numbers of nesting sea turtles can be overestimated by nearly a factor of two. Proc R Soc B 284:20162581. https://doi.org/10.1098/rspb.2016.2581

Esteban N, Unsworth RKF, Gourlay JBQ, Hays GC (2018) The discovery of deep-water seagrass meadows in a pristine Indian Ocean wilderness revealed by tracking green turtles. Mar Pollut Bull 134:99-105. https://doi.org/10.1016/j.marpolbul.2018.03.018

Esteban N, Mortimer JA, Stokes HJ, Laloë J-O, Unsworth RKF, Hays GC (2019) Sea surface temperatures influence global green turtle dietary patterns. Mar Biol. (In review)

Frazier J (1971) Observations on sea turtles at Aldabra Atoll. Philos Trans R Soc Lond B 260:373-410. https://doi.org/10.1098/ rstb.1971.0019

Fukuoka T, Narazaki T, Kinoshita C, Sato K (2019) Diverse foraging habits of juvenile green turtles (Chelonia mydas) in a summerrestricted foraging habitat in the northwest Pacific Ocean. Mar Biol 166:25. https://doi.org/10.1007/s00227-019-3481-9

Garnett ST, Price IR, Scott FJ (1985) The diet of the green turtle, Chelonia mydas (L.), in Torres Strait. Wildl Res 12:103-112. https:// doi.org/10.1071/WR9850103

González Carman V, Botto F, Gaitán E, Albareda D, Campagna C, Mianzan H (2014) A jellyfish diet for the herbivorous green turtle 
Chelonia mydas in the temperate SW Atlantic. Mar Biol 161:339349. https://doi.org/10.1007/s00227-013-2339-9

Government of Seychelles (2017) Nomination of Aldabra Group as national park and Amirantes to fortune bank as area of outstanding natural beauty. http://seymsp.com/. Accessed 14 May 2018

Gullström M, de la Torre-Castro M, Bandeira SO, Björk M, Dahlberg M, Kautsky N, Rönnbäck P, Öhman MC (2002) Seagrass ecosystems in the western Indian Ocean. Ambio 31:588-596. https://doi. org/10.1579/0044-7447-31.7.588

Hasbún CR, Lawrence AJ, Samour JH, Al-Ghais SM (2000) Preliminary observations on the biology of green turtles, Chelonia mydas, from the United Arab Emirates. Aquatic Conserv Mar Freshw Ecosyst 10:311-322. https://doi.org/10.1002/1099-0755(20000 9/10)10:5\%3c311:AID-AQC414\%3e3.0.CO;2-Z

Hays GC, Speakman JR (1991) Reproductive investment and optimum clutch size of loggerhead sea turtles (Caretta caretta). J Anim Ecol 60:455-462. https://doi.org/10.2307/5290

Hays GC, Glen F, Broderick AC, Godley BJ, Metcalfe JD (2002) Behavioural plasticity in a large marine herbivore: contrasting patterns of depth utilisation between two green turtle (Chelonia mydas) populations. Mar Biol 141:985-990. https://doi. org/10.1007/s00227-002-0885-7

Hays GC, Fossette S, Katselidis KA, Mariani P, Schofield G (2010) Ontogenetic development of migration: lagrangian drift trajectories suggest a new paradigm for sea turtles. J R Soc Interface 7:1319-1327. https://doi.org/10.1098/rsif.2010.0009

Hays GC, Mortimer JA, Ierodiaconou D, Esteban N (2014) Use of long-distance migration patterns of an endangered species to inform conservation planning for the world's largest marine protected area. Conserv Biol 28:1636-1644. https://doi.org/10.1111/ cobi. 12325

Hays GC, Alcoverro T, Christianen MJ, Duarte CM, Hamann M, Macreadie PI, Marsh HD, Rasheed MA, Thums M, Unsworth RK, York PH (2018) New tools to identify the location of seagrass meadows: marine grazers as habitat indicators. Front Mar Sci 5:9. https://doi.org/10.3389/fmars.2018.00009

Hirth HF, Klikoff LG, Harper KT (1973) Seagrasses at Khor Umaira, peoples democratic Republic of Yemen with reference to their role in diet of green turtle, Chelonia mydas. Fish Bull 71:1093-1097

Howell LN, Reich KJ, Shaver DJ, Landry AM Jr, Gorga CC (2016) Ontogenetic shifts in diet and habitat of juvenile green sea turtles in the northwestern Gulf of Mexico. Mar Ecol Prog Ser 559:217229. https://doi.org/10.3354/meps 11897

Kalugina-Gutnik AA, Perestenko LP, Titlyanova TV (1992) Species composition, distribution and abundance of algae and seagrasses of the Seychelles Islands. Atoll Res Bull 369:67. https://doi. org/10.5479/si.00775630.369.1

Kelkar N, Arthur R, Marbà N, Alcoverro T (2013a) 7 Greener pastures? High-density feeding aggregations of green turtles precipitate species shifts in seagrass meadows. J Ecol 101:1158-1168. https:// doi.org/10.1111/1365-2745.12122

Kelkar N, Arthur R, Marba N, Alcoverro T (2013b) Green turtle herbivory dominates the fate of seagrass primary production in the Lakshadweep islands (Indian Ocean). Mar Ecol Prog Ser 485:235-243. https://doi.org/10.3354/meps 10406

Lal A, Arthur R, Marbà N, Lill AW, Alcoverro T (2010) Implications of conserving an ecosystem modifier: increasing green turtle (Chelonia mydas) densities substantially alters seagrass meadows. Biol Conserv 143:2730-2738. https://doi.org/10.1016/j.bioco n.2010.07.020

Lanyon J (1986) Guide to the identification of seagrasses in the Great Barrier Reef Region. GBRMPA Special Publication Series 3. Nadicprint Services, Townsville, Queensland, Australia. ISBN 0-642-52489-0. http://hdl.handle.net/11017/279. Accessed 1 July 2017
Lauret-Stepler M, Bourjea J, Roos D, Pelletier D, Ryan P, Ciccione S, Grizel H (2007) Reproductive seasonality and trend of Chelonia mydas in the SW Indian Ocean: a 20 years study based on track counts. Endang Species Res 3:217-227

Limpus CJ, Limpus DJ (2000) Mangroves in the diet of Chelonia mydas in Queensland, Australia. Mar Turtle Newsl 89:13-15

López-Mendilaharsu M, Gardner SC, Seminoff JA, Riosmena-Rodriguez R (2005) Identifying critical foraging habitats of the green turtle (Chelonia mydas) along the Pacific coast of the Baja California peninsula, Mexico. Aquatic Conserv Mar Freshw Ecosyst 15:259-269. https://doi.org/10.1002/aqc.676

Mancini A, Phillott A, Rees A (2019) Chelonia mydas North Indian Ocean subpopulation. The IUCN red list of threatened species 2019: e.T142121108A142122995. http://dx.doi.org/10.2305/ IUCN.UK.2019-2.RLTS.T142121108A142122995.en. Accessed 30 Aug 2019

Marlow RW, Tollestrup K (1982) Mining and exploitation of natural mineral deposits by the desert tortoise, Gopherus agassizii. Anim Behav 30:475-478. https://doi.org/10.1016/S0003-3472(82)80058 $-4$

Mazaris AD, Schofield G, Gkazinou C, Almpanidou V, Hays GC (2017) Global sea turtle conservation successes. Sci Adv 3:e1600730. https://doi.org/10.1126/sciadv.1600730

Meylan AB (1978) The behavioural ecology of the west Caribbean green turtle (Chelonia mydas) in the interesting habitat. MS thesis, University of Florida, Gainesville, FL

Meylan AB (1984) Feeding ecology of the hawksbill turtle (Eretmochelys imbricata): spongivory as a feeding niche in the coral reef community. PhD thesis, University of Florida, Gainesville, FL. https://doi.org/10.5962/bhl.title.49069

Mortimer JA (1981) The feeding ecology of the West Caribbean green turtle (Chelonia mydas) in Nicaragua. Biotropica. https://doi. org/10.2307/2387870

Mortimer JA (1982) The feeding ecology of sea turtles. In: Bjorndal KA (ed) Biology and Conservation of Sea Turtles. Smithsonian Institution Press, Washington, DC, pp 103-109

Mortimer JA (1984) Marine turtles in the Republic of the Seychelles: status and management. IUCN Conservation Library, Gland

Mortimer JA, von Brandis RG, Liljevik A, Chapman R, Collie J (2011) Fall and rise of nesting green turtles (Chelonia mydas) at Aldabra Atoll, Seychelles: positive response to four decades of protection (1968-2008). Chelonian Conserv Biol 10(2):165-176

Nagaoka SM, Martins AS, dos Santos RG, Tognella MMP, de Oliveira Filho EC, Seminoff JA (2012) Diet of juvenile green turtles (Chelonia mydas) associating with artisanal fishing traps in a subtropical estuary in Brazil. Mar Biol 159:573-581. https://doi. org/10.1007/s00227-011-1836-y

Owens DW (1980) The comparative reproductive physiology of sea turtles. Am Zool 20:549-563. https://doi.org/10.1093/icb/20.3.549

Parker DM, Dutton PH, Balazs GH (2011) Oceanic diet and distribution of haplotypes for the green turtle, Chelonia mydas, in the central North Pacific. Pac Sci 65:419-431. https://doi. org/10.2984/65.4.419

Price JT (2016) Characterization of the juvenile green turtle (Chelonia mydas) microbiome associated with the ontogenic shift from pelagic habitats to inshore resident areas. MS thesis. Indiana University-Purdue University Fort Wayne, Fort Wayne, IN

Prior B, Booth DT, Limpus CJ (2016) Investigating diet and diet switching in green turtles (Chelonia mydas). Aust J Zool 63:365375. https://doi.org/10.1071/ZO15063

Quiñones J, Carman VG, Zeballos J, Purca S, Mianzan H (2010) Effects of El Niño-driven environmental variability on black turtle migration to Peruvian foraging grounds. Hydrobiologia 645:69-79. https://doi.org/10.1007/s10750-010-0225-8 
R Core Team (2017) R: a language and environment for statistical computing. www.R-project.org. Accessed 1 May 2018

Reich KJ, Bjorndal KA, Bolten AB (2007) The 'lost years' of green turtles: using stable isotopes to study cryptic life stages. Biol L 3(6):712-714

Ross JP (1985) Biology of the green turtle, Chelonia mydas, on an Arabian feeding ground. J Herpetol. https://doi.org/10.2307/1564198

Scott R, Hodgson DJ, Witt MJ, Coyne MS, Adnyana W, Blumenthal JM, Broderick AC, Canbolat AF, Catry P, Ciccione S, Delcroix E (2012) Global analysis of satellite tracking data shows that adult green turtles are significantly aggregated in marine protected areas. Glob Ecol Biogeogr 21:1053-1061. https://doi.org/10.11 11/j.1466-8238.2011.00757.x

Seminoff JA (2004) IUCN Global status assessment green turtle (Chelonia mydas). https://mtsg.files.wordpress.com/2010/07/mtsg_ chelonia_mydas_assessment_expanded-format.pdf. Accessed 24 Oct 2018

Seminoff JA, Allen CD, Balazs GH, Dutton PH, Eguchi T, Haas HL, Hargrove SA, Jensen MP, Klemm DL, Lauritsen AM, MacPherson SL, Opay P, Possardt EE, Pultz SL, Seney EE, Van Houtan KS, Waples RS (2015) Status review of the green turtle (Chelonia mydas) under the US Endangered Species Act. NOAA Technical Memorandum, NOAANMFS-SWFSC-539. 571 pp. http://www. swfsc.noaa.gov. Accessed 2 June 2019

Shimada T, Aoki S, Kameda K, Hazel J, Reich K, Kamezaki N (2014) Site fidelity, ontogenetic shift and diet composition of green turtles Chelonia mydas in Japan inferred from stable isotope analysis. Endang Species Res 25:151-164. https://doi.org/10.3354/esr00 616

Short FT, Coles R, Waycott M, Bujang JS, Fortes M, Prathep A, Kamal AHM, Jagtap TG, Bandeira S, Freeman A, Erftemeijer P, La Nafie YA, Vergara S, Calumpong HP, Makm I (2010) Thalassodendron ciliatum. The IUCN Red List of Threatened Species 2010: e.T173375A7002484 (downloaded on 1 Oct 2018). https://doi. org/10.2305/iucn.uk.2010-3.rlts.t173375a7002484.en

Stoddart DR, Poore MED (1970) Geography and ecology of Farquhar Atoll. Atoll Research Bull 136:7-27

Thomson JA, Whitman ER, Garcia-Rojas MI, Bellgrove A, Ekins M, Hays GC, Heithaus MR (2018) Individual specialization in a migratory grazer reflects long-term diet selectivity on a foraging ground: implications for isotope-based tracking. Oecologia 188(2):429-439. https://doi.org/10.1007/s00442-018-4218-z

Trevathan-Tackett SM, Macreadie PI, Sanderman J, Baldock J, Howes JM, Ralph PJ (2017) A global assessment of the chemical recalcitrance of seagrass tissues: implications for long-term carbon sequestration. Front Plant Sci 8:925. https://doi.org/10.3389/ fpls.2017.00925

Tucker AD, Read MA (2001) Frequency of foraging by gravid green turtles (Chelonia mydas) at Raine Island, Great Barrier Reef. J Herpetol 35:500-503. https://doi.org/10.2307/1565970

Vander Zanden HB, Arthur KE, Bolten AB, Popp BN, Lagueux CJ, Harrison E, Campbell CL, Bjorndal KA (2013) Trophic ecology of a green turtle breeding population. Mar Ecol Prog Ser 476:237249. https://doi.org/10.3354/meps10185

Vélez-Rubio GM, Cardona L, López-Mendilaharsu M, Souza GM, Carranza A, González-Paredes D, Tomás J (2016) Ontogenetic dietary changes of green turtles (Chelonia mydas) in the temperate southwestern Atlantic. Mar Biol 163:57. https://doi.org/10.1007/ s00227-016-2827-9

von Brandis RG, Mortimer JA, Reilly BK, van Soest RWM, Branch GM (2014) Diet composition of hawksbill turtles (Eretmochelys imbricata) in the Republic of Seychelles. West Indian Ocean J Mar Sci 13:81-91

Waycott M, McMahon K, Mellors J, Calladine A, Kleine D (2004) A guide to tropical seagrasses of the Indo-West Pacific. James Cook University, Queensland

Whiting SD, Macrae I, Thorn R, Murray W, Whiting AU (2014) Sea turtles of the Cocos (Keeling) Islands, Indian Ocean. Raffles Bull Zool 30:168-183

Wickham H (2016) ggplot2: elegant graphics for data analysis, 2nd edn. Springer, New York

Wild Singapore (2016) Wild Fact sheets: Sickle seagrass Thalassia hemprichii. Downloaded from www.wildsingapore.com/wildfacts/ plants/seagrass/thalassia.htm. Updated October 2016

Publisher's Note Springer Nature remains neutral with regard to jurisdictional claims in published maps and institutional affiliations. 